Marchak, M. Patricia. 1988. Ideological Perspectives on Canada. 3d ed. Toronto: McGraw-Hill Ryerson Ltd.

Opoku-Dapaah, Edward. 1993. "Directory of African Community Groups in Metropolitan Toronto." Toronto: Centre for Refugee Studies/York Lanes Press.

Richmond, Anthony H. 1994. Global Apartheid: Refugees, Racism, and the New World Order. Toronto, New York and Oxford: Oxford University Press.

Romberg, Perry. 1994. "Service Delivery to Refugees and Immigrants: Toward an Integrated Approach." Refuge 13, na. 9.

Rudge, Philip. 1992. "The Asylum Dilemma-Crisis in the Modern World: A European Perspective." In Refugees and the Asylum Dilemma in the West, edited by Gil Loescher. Pennsylvania: Pennsylvania State University.

Samuel, T. John. 1990. "Third World Immigration and Multiculturalism." In Ethnic Demography: Canadian Immigrant, Racial and Cultural Variations, edited by Shiva S. Halli et al. Ottawa: Carleton University Press.

Continued from page 33/

Toward a Community-Based Approach ...

\section{Bibliography}

Breon, Robin. 1989. "Torture Requires Special Care." Ontario Medicine 8, no. 18 (September): 16.

Canadian Centre for Victims of Torture. 1995. Introductory Literature.

- 1994. Quarterly, no. 8, January. 1994. Quarterly, no. 9, September.

Canadian Task Force on Mental HealthIssues Affecting Immigrants and Refugees. 1988. "Victims of Catastrophic Stress." In After the Door Has Been Opened: Mental Health Issues Affecting Immigrants and Refugees in Canada. Toronto.

Chambon, Adrienne, Joan Simalchik, and Mulugeta Abai. 1997. "The Canadian Centre for Victims of Torture, Toronto: Transforming Relations between Refugees, Professionals, and the Community." In Community Development Around the World: Practice, Theory, Research, Training, edited by Hubert Campfens. Toronto: University of Toronto Press.

Hossie, Linda. 1991. "Hiding Our Eyes From Horrible Truths." Globe and Mail, September 10. $\square$

\title{
Toward a Community-Based Approach to Healing: A Case Study of the Canadian Centre for Victims of Torture
}

\author{
Mulugeta Abai and Lydia Sawicki
}

\section{Abstract}

This paper provides insights about the operations of the Canadian Centre for Victims of Torture (CCVT). It argues that unlike clinical approaches to health care, the Centre's strategy is unique in that it is oriented toward "breaking the circles of silence and building circles of solidarity." The CCVT provides direct services to clients as well as providing linkages to other services, including networking with lawyers and officials involved in the refugee determination process. The paper draws attention to the needs of victims of torture and specific groups such as women, and the many reasons why there is often a time delay before they seek services.

\section{Précis}

Cet article fournit des informations d propos des opérations du Centre Canadien pour les Victimes de Torture (Canadian Centre for Victims of Torture-C(VT). Il développe une argumentation selon laquelle la stratégie du Centre est d la fois unique et totalement distincte de l'approche clinique des soins de santé, puisqu'elle se fonde sur une orientation visant $\dot{d}$ "briser les cercles $d u$ silence et construire les cercles de la solidarité". Le CCVT fournit des services directs à sa clientele mais aussi établit la liaison entre sa clientèle et d'autres services, ce qui inclut notamment les prises de contacts avec les juristes et les officiels impliqués dans le processus d'obtention du statut de réfu-

Mulugeta Abai is Executive Director, Canadian Centre for Victims of Torture, Toronto.

Lydia Sawicki is Project Coordinator, Centre for Refugee Studies, York University, Toronto.

The views expressed in this paper are those of the authors, not necessarily those of their institutions. gié. L'article attire l'attention sur les besoins des victimes de tortures, et, parmi celles-ci, de certains groupes spécifiques comme les femmes, en attirant notamment l'attention sur les raisons qui expliquent le laps de temps que ces victimes doivent parfois laisser se dérouler avant de se décider à réclamer du support.

The discourse around fiscal restraint and restructuring efforts conceptualises refugees and immigrants only as a costly burden to the public purse. Little discussion prevails regarding what the influx of newcomers has historically contributed and continues to contribute in the shape of our evolving ethnic composition. Certainly, this country's potential for a just, harmonious and prosperous twenty-first century is embedded beyond this question. Through its service delivery approach and grassroots political activity, the Canadian Centre for Victims of Torture (CCVT) challenges a conceptualisation of a racist, anti-immigrant sentiment. It does so by a community-based approach to healing that effectively breaks the silence and stigmatisation related to immigrants in general, through its focus on the healthier integration into Canadian society of victims of trauma and torture.

The CCVT provides long-term direct services to clients living in the City of Toronto and beyond. By contributing an integrated network of programs and services that are culture- and situation-sensitive, involving the family and the community in the process, the CCVT has assisted more than 8,000 survivors of torture and war from 99 different countries since it began in 1983. Community involvement in the CCVT is characterised by volunteers, 
staff members, a wide array of professionals who provide expertise and services, the clientele itself integrating and supporting the programs and supporting each other, and the Canadian public that helps finance and participates in the workshops and information sessions. Many of these participants are torture or trauma survivors themselves and are able to provide a sensitive and effective approach to service design and practice. The vulnerable and isolated conditions of victims of torture or trauma necessitate a highly sensitised, communitybased approach to healing, as the CCVT has managed to finance up until now. While the atmosphere maybe politically charged, CCVT still must focus unreservedly on the needs of clients and their problems. Faced with fiscal restraint and restructuring and its appropriate discourse, CCVT struggles to facilitate successful community integration and enrichment through service delivery and educational programs and policies.

This chapter provides a closer look at the programs and operations of the Canadian Centre for Victims of Torture (CCVT). It argues that unlike clinical single-faceted approaches to health care, the Centre's strategy is unique in that it is oriented toward breaking the circles of silence and building circles of solidarity within the family and the community. These circles not only serve to assist with the needs of new Canadians living out prolonged posttraumatic phases but they also serve to inform more and more sectors of Canadian society about torture as a prevalent and persistent scourge.

The first task this paper undertakes is to outline some specific needs of victims of torture and trauma and the even more specific needs of women, children and the elderly. It will note how the CCVT's service delivery mandate and program design have ensured the utmost sensitivity and best possible effectiveness with regard to those needs. That is to say, by discussing the CCVT's programmatic and service delivery approach, this paper will show how the integration of the community best addresses the needs of large but silenced populations of new Canadians and ensures a harmonious and prosperous integration.

While the lingering effects of traumatic experiences, often called Posttraumatic Stress Disorder, demand a very specific array of services within the refugee community, women, children and the elderly are often even more isolated and in need of culturally and situationally sensitive services. All tortured and traumatised refugees and immigrants not only require a unique array of services to ensure successful integration, but how those services are delivered is also extremely important. For example, due to life threatening and degrading previous experiences, trust is a key issue for many of the CCVT's clients and is an obstacle to unconstrained service delivery and of the smooth integration of this population. Both the Canadian Medical Group of Amnesty International and the CCVT "agree that the goal of torture is to destroy personality, not to extract confessions" (Canadian Task Force on Mental Health Issues 1988, 85). Therefore, special efforts must be made to assist in the healing of that personality damage and in addressing its accompanying distrust.

The CCVT reports that tortured and traumatised newcomers suffer not only the physical after-effects of torture but they also suffer

[p]sychological symptoms [that] frequently include anxiety, depression, irritability, paranoia, guilt, suspiciousness, sexual dysfunction, loss of concentration, confusion, insomnia, nightmares, concentration difficulties, impaired memory and memory loss. (CCVT Introductory Literature)

Service delivery, in light of these conditions, must be delivered with extra sensitivity on the part of the healthcare professional and sensitive counselling is often needed in order to rebuild the patient's identity, personality, self-esteem, confidence and their capacities for social interaction. The CCVT's community-based approach to healing ensures that barriers are broken down that isolate the tortured or traumatised client, using a network of community members that befriend, counsel, heal, listen to, advise, refer. Further, the CCVT goes further to advocacy and education by both informing the client and the community at large about torture in the world and its after-effects in victims and by participating in policy discussions with other advocacy groups and the Federal and Provincial governments.

Other concerns must address women, children and the elderly who require even more specific approaches to healing and integration. Although women and girls make up a large portion of the refugee population in Canada, few of those that have been tortured or traumatised come forward for help. This is often because the torture inflicted on women and girls renders them even more seriously stigmatised as it not only involves rape but the torture of women and girls jeopardises the culturally-specific role of men protecting women family members. The CCVT makes efforts to reach women and girls who are experiencing physical and psychological pain and are isolated within their communities and their families due to these experiences. The Centre's community network takes special time and care in the program design and delivery to breakdown those barriers and encouraging better understanding and relationships within the community.

The restructuring and spending restraints within the refugee service sector threaten these programs, the victims of torture and trauma, and the communities that are unable to offer the adjustment assistance that is so evidently needed. All levels of government are responsible for ensuring that this internationally renowned, innovative and cost effective centre count with adequate resources. The CCVT has become a flagship for Canada and is the only centre that offers comprehensive and appropriate services and programs for victims of torture and trauma. 